\title{
A Reflection on the Collapse of the Power of the Church and the Rise of Science Authority
}

\author{
Fathor Rasi \\ Research associate at Centre for Strategic Studies, University of Indonesia and Secretary General, Forum \\ Inteligensia Bebas (FIB) or Forum for Free Intelligensia, Jakarta. \\ fath.rasi@gmail.com
}

\section{Abstract}

This article explains that the Modern period marked by the collapse of the power of the church and the rise of science authority. At the next phase, the new image of man becomes inevitable. After modernist philosophers called on people to go away from the church, science in turn lock and catch the man, then he is traped in factories and industries. Substantive dimensions in man is eliminated, so that his presence in the world is subordinated by the industrial machines. Human in modern world is not more than a "the screw of industry.
Keywords

modern man; industry, church;

science; human

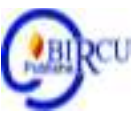

\section{Introduction}

Actually, the 19th century can be regarded as a century in which all beliefs and expectations of enlightenment reach its peak. It is the age where all teachers of science, especially natural sciences, have discarded the belief of God. The scientists and scholars are openly defending atheism. It is not as happen, but they regard themselves as forward thinkers, people who promote the humanity but they still believe in God they considered as old-fashioned people who still tie with superstition and tradition.

The crisis and instability the foundation of philosophy had occured in the Middle Ages up to the 14th century that lasted until the 15th century, then in the 15th century and the 16th was followed by a period called the Renaissance.

The emanation of the renaissance's human concept then successfully inspired the modern period which born some outstanding philosophers such as Hegel and Marx who reduce human beings as a simple element in society. Including modern naturalism or the view that Darwinism, plants, animals, and humans as a living thing (Animate), a type of biological beings are composed of cells that interact in the organic-and then organized into a unity-which manifests itself in the next stage, life, and died that all was caused by a biological process established by the laws of nature. Human is another form of animal but is equipped with the brain and more complex nervous system. Here, there is no room to talk about a mysterious substance because naturalism stands on the principle of what can be observed and tested scientifically (what is observable and experimentable).

The emergence of Renaissance is as a correction, and it's opposed to traditional idea for the sake of the awakenig of human autonomy. Roger Bacon (1214-1294), Copernicus (1473-1543), Francis Bacon (1561-1626), Tycho Brahe (1546-1601), Johannes Kepler (1571-1630), and Galileo Galilei (1546-1642) are prominent figures in the renaissance period. Then we have arrived to the next period which is known as "Modern." In this chapter the writer focus on the analysis of the pillars of modernism as well as modern world view especially on the views of man which is offered by Emperism, Materialism, and Existensialisme. The emergence and main purpose of those modern ideologies, base on their claims, is to raise human dignity, glory and for the sake of their future. 


\section{Review of Literature}

\section{Modernism}

According to F. Budi Hardiman, the word of "Modern", is derived from the Latin word 'moderna', which means 'new' or 'present,' from its original meaning we can say that human being live in this 'modern' era as far as 'the present time' become his consciousness. Many historians agree that arround the years of 1500 was the day of birth of the modern era in Europe. Therefore, modernity is not only refer to the period, but also a state of consciousness associated with 'newness'. Therefore the terms of change, progress, revolution are the key terms of modern consciousness.

A slightly different view, but with the same essence, is proposed by Dominique Wolton formulate on how the spectrum of the idea of modernism. He argued that, modernity is characterized by distrust, the rejection of tradition, the privilage given to the individual, and the interests in freedom is unavoidable; belive in reason, progress, and science; cut off society from the sacred and religion through the process of secularization.

In the Modern period, as was wiewed by Betran said Russel, is marked by the collapse of the power of the church and the rise of science authority. At the next phase, the new image of man becomes inevitable. After modernist philosophers called on people to go away from the church, science in turn lock and catch the man, then he is traped in factories and industries. Substantive dimensions in man is eliminated, so that his presence in the world is subordinated by the industrial machines. Human in modern world is not more than a "The screw of industry".

Rene Descartes, a France philosopher, who is known as a father of modern philosophy and the founder of Rationalism. When Descates uttered, 'I think, therefore I am' (cogito ergo sum), he placed his individual awareness of his own limited self as the criterion of existence, for certainly the ' $\mathrm{I}$ ' in Descartes's assertion wasn't the Divine 'I' which alone, according to traditional doctrines. But, with Cartesian rationalism, individual human existence became the criterion of reality and also the truth.

There was nothing higher in man than his reason and nothing higher in the objective world than what that reason could comprehend with the help of the normal human senses. And since modern man refused to accept a principle higher than himself. Obviously all that issued from his mind and thought could not be but anthropomorphic.

\section{Discussion}

\subsection{Empiricism}

In contrast to rationalism which assumes that the validity of knowledge is obtained only through ratio, empirism believe that a valid knowledge must come from experience (emperia). By this this principle, then their view then called "emperism." This group try to free himsself from spiritual speculation which then marked the collapse of traditional metaphysics. The pioneers of this ideology are Hobbes, Lock, Bekeley, and Hume. The main source of knowledge, according to empiricism, is sensory experience. It delivers sensation concerning the world and delivers inner experience (reflection) concerning man's person. Meanwhile, man mind only works and serves to organize and process the matter and data obtained through sensory experience. Therefore, empiricisms believe that man has no innate ideas as it has been said by rationalisms.

One of the outstanding figures of empiricim is Hobbes (1588-1679). He asserts that philosophy is no longer deals with theology, the objects of philosophy has turned to be more outwardly, the objects that can be experienced through our bodies only. Any talk like God, 
and also untouchable constant substances like angels, spirits, and others, must be removed from philosophical reflection.

Hobbes tries to destroy traditional metaphysic. Hobbes argued that, the fact (truth) can be obtained and experienced through external senses. Automatically God as the first cause in the Middle Ages is rejected by Hobbes. He clearly said that the first principle of reality is matter and motion. Spiritual concepts are no longer relevant to philosophy.

Hobbes's view on man is totally using empirical approach. Hobbes sees man as a multisocial engine. They often compete and clash each other. In their competition, men should fight each other in zeising scarce resources, to protect what they have from others, and even subjugate others. And the power is an instrument to realize his self interest because man basically wan to dominate the others. What has occured in social life no less than bellum omnia contra omnes, or a war of all against all. In the war, man is a wolf to his fellow man, homo homini lupus.

Hobbes disagrees with Descartes's views on soul as a spiritual substance. According to Hobbes, the whole world, including man, is continually process upon the laws of mechanism. Man is not more than a part of material world surrounding him. Therefore, every phenomena in human being can be explained as the ways as occurs in natural phenomena in term of mechanical point of view. Man can survive as long as their blood circulation and heart work properly, which is caused by mechanical influence of the atmospheric air. Thus, man who is alive is no other than the motion the members of his body. Of course this opinion as compared with Islam is very contradictory, because the man -although physically has diedbut his soul remains alive. Even for a Mukmin, the death is a continuation of eternal life.

In the Hobbes's philosophy, the concept of soul has lost its metaphysical character. Soul has changed into matter and motion. Feelings in human beings is the input from the outside through the five senses which produces a reaction either approach or make distance the object. If it approached, the reaction called "lust" like the feeling of pleasure, joy, love. But if make a distance the reaction is called "equivocation," such as hatred, sadness, fear and so forth. Man according to Hobbes, is a being who basically want to satisfy his self-interest to seek pleasure and avoid pain. A wise man is able to maximize the fulfillment of human desires for individual welfare.

For Hobbes everything in this world is under material law, man is emerge from this material world surrounding him. Therefore, all things that happened to him can be explained in the same way both nautrally and mechanically. Human will survive if his blood circulation and heart work well, which is caused by mechanical influence of the atmospheric air. Human's life is a motion of the organs of his body. The soul is a complex form of mechanical processes within the body. Aql (reason) is not innate, but rather the result of the development because of his will to strive. The will in beginning is a small movement, which if it's directed toward something, called a desire, has the same meaning with love, and if its directed to go away or leave something called reluctance, which is equal with hatred. memories, happiness and unhappiness, and all psychical phenomena, rely on the mechanical views.

'The same idea has also been explained by David Hume. In the case of religion, Hume seemingly very critical, and if we trace back from the empirism's teaching, Hume is more consistent than John Locke and Barkley. Locke still acknowledges material and spiritual substance, even Barkley confirmed that the substance of God is the basis of any other substance. While Hume jumps further than that, by doubting the existence of God because there is no strong argument to prove the existence of God either a posteriori or a priori. We only know that this nature is matter. If we assume an alignment of cause and effect, we would say that nature is caused by the material cause, not because of the spiritual. Then assertively 
he refused miracle as one of the basic religious beliefs. According to him, the main source of religion is superstition. Man in the first time found a mirror in nature and then create gods according to individual taste. The philosophers and theologians function as a drug seller and a spiritual preacher of what is desired by Man.

Sometimes words such as soul and God are frequently use by scientist and writers in book titles (often in big bold letters) to attract readers, but these words are rarely defined, scientifically or otherwise, and the important human issues dealing with these concepts are also rarely discussed.

Thus, Hume denies the existence of "I" which is embeded spiritual substance. He never find "I" which stands alone. He find "I who get angry", "I fear" and so forth. Even according to Hume, what we have seen is just impressions only. Therefore, the so-called "I" is actually a composition or arrangement of the impressions. Hume further states that, there is no evidence to prove that God is exists or He takes a part in the world, also there is no evidence that soul is eternal.

\subsection{Materialism}

After the Renaissance, when philosophy and religion in Europe went through a crisis, atheism and materialism more or less came into vogue. In the nineteenth century, some biologists and physicians such as Vogt, Buchner, and Ernst Haeckel emphasized the fundamentality of matter and the denial of metaphysics, but the most important materialist school of philosophy was that founded by Marx and Angle.

In the mid-19th century this ideology emerged in German philosophy. This ideology has also taken part in building and strengthening the pillar of modernism. Materialism is a school of thought and the holders of this ideology think of matter only and give no importance to soul. For them reality is matter, while the consciousness or the human mind is just the symptoms secondary from the material processes alone. For materialism, the human mind has no ontological status, because it won't be exist without the material processes.

Materialism was first built by Ludwig Feuerbach, a German-born philosopher. He studied theology in Heidelberg and Berlin to Hegel's philosophy. Feuerbach was among the disciples of Hegel from the left wing. He received his dialectical method but rejected the contents of his teachings. He is the first who change of Hegel's idealism into materialism.

Feuerbach's view that, the more we imagine about the perfection of God, the greater the alienation of man. Since Christianity is the most noble religion, then the religion at once became the most powerful factor of human alineation of his nature. Therefore, those who want to get back his glory they must must devorce from religion.

In this case, Feuerbach acknowledged that religion is one of the fundamental categories of human life. However, the power of God and the gods have lasted long enough. Furthermore, Human being has become mature to end this alienation and now its time to get back the totality of his nature. Feuerbach said that if the sacred of nature is the basis of all religions, including Christianity, then the holliness of human being should be the final destination. The most important starting point in the history is when human being has become aware that the only God for human is himself, Homo Homini Deus.

Feuerbach said that man is not created by God, but rather God is created by man, through a process called projection. Man found in its own infinity within himself, and it was then regarded as something which stands independently, out of human himself. The Infinity was then assumed as God. God, who is just a creation of man, then adored and respected in their prayer and worship. It means that man becomes slaves of his own creation. As a result Man sees himself as a creation of his own thought. Man has projected his freedom out of himself above of his creation. finally man loses something. He was exiled, alienated from 
himself. So, to be cured of this alienation, man should aware of this process. Man must understand that God only is the creation of his own, so he would from his slavery. Man now has become a creature of his own creation, man can bring back both of his nature and freedom if he understand his mistake.

Feuerbach's projection theory was taken over by Karl Marx, Nietzsche, Frued, and Sartre. But Feuerbach's opinion about the role of religion is quite different from their opinions. According to Feuerbach religion has taught how great human is. All men dreams have been formed and named of God. This means that religion teach us about human nature, But Feuerbach then changed theology into anthropology. Theos, God, is not the origin of human being. but precisely Human is the origin of God.

God is the greatest dream in the human heart, human feels free and blessed in his religion. In religion, man celebrate his Sunday. God is revealed from the deepest of the human heart. God is the center of feeling. Therefore, God has become man and God has awakened from the dead. To Feuerbach, God's attributes are just the projections of human desires.

For Feuerbach, theology is very important, not in the doctrine of God, but as anthropology. Theology teaches much about human beings. Man is the center, the beginning and end of religion. All human relationships are formed in religious context. Therefore theology should be read as anthropology. The first and most important commandment is "Homo homini Deus est" (human is God for his fellow being).

This Materialism, which pioneered by Feuerbach, then is matured by Karl Marx (18181883). Karl Marx is the most prominent and influential figure after Feuerbach. Marx supported the idea of Feuerbach espescially his view that everything is in the term of nature, including human. Nevertheless according to Karl Marx, Feuerbach's thoughts hadn't been concrete yet because Feuerbach did not glorify human being from other natural objects. As gattung (natural beings), according to Marx, human beings must be distinguished from animals because he is a social creature, a creatures that involved in the production process, and in employment and ownership.

Marx agrees with Feurbach's view that man should be seen as a Gattung, as natural beings. If we talk about human beings we should not make him as an abstract figures or out of this world. We must talk about human being here and know including human world, namely the state, society. From his research Marx research found, that human life is only controlled by economic relations. All spiritual activity, either science or art, religion, morality and so forth, is actually the deposition of the economic relations which are determined by history. Based on the principles of the human being should not be viewed in the abstract being. Human should be viewed as a concrete being, namely in his relation to world surrounding him, as a worker being. Human nature is a worker (laborans homo, homo faber).

\section{Conclusion}

Seemingly, the critics of both Feuerbach and Marx have the same basis, namely humanism. Human must be returned to his true origin. Feuerbach has emphesized human being a part of the natural-material world, the nature of man has been wrapped by false beliefs. Therefore, according to Feuerbach, as mature being, man should be able to divorce himself from these religious delusions, in order to achieve the real nature of himself. Whereas Marx views that human being as social creatures who are confined by the social structure itself, so that he can not reveal his real nature within the structure. Religion and State, according to Marx, is a structure which is the most influential factor in the exploitation of human identity. By eliminating the social structures and classes in society, human will get 
back his real nature, which is a society without classes and automatically the illusions and promises of religion will be lost.

Finally this ideology comes to conclusion the whole reality including human beings, can be explained solely in terms of matter and energy. From this viewpoint, any talk of human beings as having a mind, soul, self, personality, as if any of these things existed separate from their bodies and brains, is merely an expansionist "error" and really no basis in fact. The extreme form of this view would say that there is no god or supranatural, no mind, inner self, spirit or person.

\section{References}

Franz Magnis Suseno, Menalar Tuhan, (Yogyakarta: Penerbit Kanisius, 2006), p. 5.

Harun Hadiwijono, Sari Sejarah Filsafat Barat 2 (Yogyakarta: Kanisius, 1980.), p. 11. See also Charles Le Gai Eaton, Islam and The Destiny of Man, (USA: State University of New York Press, Albany, 1985), p 191

Jacques P. Thiroux, Philosophy Theory and Practice (New York: Macmillan Publishing Company, 1985), p. 69

Francisco Budi Hardiman, Filsafat Modern: Dari Machiavelli Sampai Nietzsche, (Jakarta: Gramedia Pustaka Utama, 2007), p. 2-3

Tariq Ramadan, Menjadi Modern Bersama Islam: Islam, Barat, dan Tantangan Modernitas, terj. Zubair dan Ilham B. Saenong (Jakarta: Teraju, 2003), p.5

Bayraktar Bayrakli, Eksitensi Manusia: Perspektif Tasawuf dan Filsafat Mengatasi Problema Eksistensial Manusia Jalaluddin Rumi Sampai Filosof Kontemporer, translated. Suharsono (Jakarta: Perenial Press, 1996), p. 1-2

Seyyed Hossein Nasr, Traditional Islam in the Modern World, (London and New York: Kegan Paul International, 1987), p. 100-101

Juhaya S. Praja, Aliran-Aliran Filsafat dan Etika, (Bandung: Yayasan Piara, 1997), p. 72-73

Amsal Bakhtiar, filsafat Agama, (Jakarta: Logos Wacana Ilmu, 1997), p. 112

Fred Alan Wolf, The Spiritual universe, (New York: Simon and Schuter, 1996), p. 23

Muhammad Taqi Misbah Yazdi, Philosophical Instructions: An Introduction to Contemporary Islamic Philosophy, (New York: (Institute Global Cultural Studies (IGCS) Binghamton University, Center for the Preservation of Ancient Religious Text ( Binghamton University, 1999), p. 22

Paul Edward (ed.), The Encyclopedia of Philosophy, (New York: Macmillan Publishing Co, 1972), vol. 5-6, p. 179-180

About relation between Hegel with Feuerbach, see in Frederick Copleston, A History of Philosophy, Volume 7, hal.293-298. See also Francisco Budi Hardiman, Filsafat Modern: Dari Machiavelli Sampai Nietzsche, p. 227-229

Amsal Bakhtiar, filsafat Agama, (Jakarta: Logos Wacana Ilmu, 1997), p. 121

Ignace Lepp, Ateisme Dewasa Ini, terj. (Yogyakarta: Shalahuddin Press, 1985), p. 68. See also TH. Huijbers, Manusia Mencari Allah, (Yogyakarta: Kanisius, 1982), p. 156-159. compare to Harry Hamersma, Tokoh-tokoh Filsafat Barat Modern, p. 64-65

Harry Hamersma, Tokoh-tokoh Filsafat Barat Modern, p. 66. see also TH. Huijbers, Manusia Mencari Allah, p. 156-158

Louis Leahy, Aliran-aliran Besar Ateisme, (Yogyakarta, Jakarta: Kanisius dan BPK Gunung Mulia, 1985), hal. 90-91. see also Francisco Budi Hardiman, Filsafat Modern: Dari Machiavelli Sampai Nietzsche, p.229-231

Harun Hadiwijono, Sari Sejarah Filsafat Barat 2, (Yogyakarta: Kanisius, 1980), p. 120 